\title{
PENGEMBANGAN INSTRUMEN ASESMEN GERAK LURUS PADA MATA PELAJARAN FISIKA SMA
}

\author{
Muhammad Nurkhalis Agriawan ${ }^{1, a}$, Muhammad Saldi ${ }^{2 . b}$, Muh. Ridwan Kadir ${ }^{3, c}$ \\ 1,2,3 Universitas Sulawesi Barat

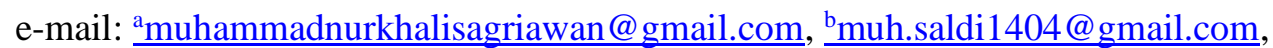 \\ cridwankadir99@gmail.com
}

\begin{abstract}
Abstrak
Penelitian ini bertujuan untuk menguji validitas, reliabilitas, tingkat kesukaran, dan daya beda dari instrumen tes yang disusun. Adapun subjek dari penelitian ini adalah peserta didik SMA kelas X sebanyak 20 orang. Metode penelitian yang digunakan adalah Research and Development (R\&D). Tahapan hasil dari penelitian ini adalah hasil pengembangan dan hasil uji coba. Hasil pengembangan yang diperoleh adalah instrumen tes berupa soal pilihan ganda. Untuk hasil uji coba, diperoleh data pada uji validitas adalah rendah. Uji coba reliabilitas $\mathrm{r} 11=-0,023072486, \mathrm{r} 11<0,20$ menunjukkan bahwa reliabilitas instrumen tes sangat rendah. Uji tingkat kesukaran soal mudah $60 \%$, sangat sukar $25 \%$, dan sedang $15 \%$. Ini menujukkan bawa tingkat kesukaran instrumen tes sedang. Uji daya beda diperoleh data tidak baik $85 \%$, baik dan sangat baik masingmasing adalah $10 \%$ dan 5\%. Ini menujukkan bahwa daya beda soal pada instrumen tes yang disusun memenuhi kategori tidak baik.
\end{abstract}

Kata Kunci: Validitas, Reliabilitas, Tingkat Kesukaran, Daya Beda

\section{DEVELOPMENT OF STRAIGHT MOTION ASSESSMENT INSTRUMENTS IN HIGH SCHOOL PHYSICS COURSES}

\begin{abstract}
This study aims to test the validity, reliability, level of difficulty, and differentiating power of the test instruments that were compiled. The subjects of this study were high school students in class $X$ as many as 20 people. The research method used is Research and Development $(R \& D)$. The stages of the results of this research are the results of development and trial results. The development results obtained are test instruments in the form of multiple choice questions. For the test results, the data obtained in the validity test is low. Test reliability $r 11=-0.023072486, r 11<0.20$ indicates that the reliability of the test instrument is very low. Test the difficulty level of easy $60 \%$, very difficult $25 \%$, and $15 \%$ moderate. This shows that the level of difficulty of the test instrument is moderate. Differentiating power test obtained data that is not good $85 \%$, good and very good are $10 \%$ and $5 \%$ respectively. This shows that the differentiating power of the questions on the prepared test instruments meets the bad category.
\end{abstract}

Keywords: Validity, Reliability, Difficulty Level, Distinctive Power

\section{PENDAHULUAN}

Beberapa faktor yang mempengaruhi keberhasilan suatu pendidikan adalah kemampuan guru dalam melakukan dan memanfaatkan penilaian, evaluasi proses, dan hasil belajar. Kemampuan tersebut sangat diperlukan untuk mengetahui tercapai tidaknya tujuan pembelajaran yang sudah ditetapkan dalam kurikulum [1]. Berkaitan dengan hal tersebut pemerintah telah memberikan pedoman yaitu dengan mengeluarkan
Permendiknas Nomor 16 Tahun 2007 tentang Standar Kualifikasi Akademik dan Kompetensi Guru mata pelajaran (termasuk guru fisika) dinyatakan bahwa kompetensi guru mata pelajaran antara lain adalah mengembangkan instrumen penilaian [2]. Prinsip dan standar penilaian menekankan dua ide pokok yaitu penilaian harus meningkatkan belajar peserta didik dan penilaian merupakan sebuah alat yang berharga untuk membuat keputusan pengajaran [3]. 
Peran pendidikan di sekolah berfokus untuk mengembangkan sumber daya peserta didik yang meliputi ranah kognitif, afektif dan psiko-motorik, atau sikap spiritual, sikap sosial, pengetahuan dan keterampilan [4]. Penilaian Pendidikan menurut Permendiknas Nomor 20 Tahun 2007 tentang Standar Penilaian Pendidikan adalah proses pengumpulan dan pengolahan informasi untuk menentukan pencapaian hasil belajar peserta didik. Penilaian merupakan kegiatan sangat penting dalam pembelajaran matematika [5]. Penilaian dapat memberikan umpan balik yang konstruktif bagi guru maupun peserta didik. Hasil penilaian juga dapat memberikan motivasi kepada peserta didik untuk berprestasi lebih baik. Bahkan penilaian dapat mempengaruhi perilaku belajar karena peserta didik cenderung mengarahkan kegiatan belajarnya menuju muara penilaian yang dilakukan guru. Kualitas instrumen penilaian hasil belajar berpengaruh langsung dalam keakuratan status pencapaian hasil belajar peserta didik. Oleh karena itu kedudukan instrument penilaian hasil belajar sangat strategis dalam pengambilan keputusan guru dan sekolah terkait pencapaian hasil belajar peserta didik.

Menurut survei yang dilakukan oleh Organisation for Economic Co-operation and Development (OECD) menggunakan tes Programme Inter-nationale for Student Assesment (PISA) tahun 2015, pendidikan di Indonesia menduduki ranking 69 dari 76 negara yang mengikuti tes PISA. Data yang dihasilkan dari tes PISA menunjukkan pentingnya guru mengarahkan peserta didiknya untuk berpikir tingkat tinggi. Salah satu faktor yang menyebab-kan kemampuan berpikirnya masih ren-dah adalah kurang terlatihnya anak Indonesia dalam meyelesaikan tes atau soal soal yang sifatnya menuntut ana-lisis, evaluasi, dan kreativitas. Soal-soal yang memiliki karakteristik tersebut adalah soal-soal untuk mengukur HOTS [6].

Penilaian yang berupa tes dapat digunakan untuk mengasah kemampuan berpikir peserta didik, dan berpengaruh dalam menentukan keterampilan berpikir peserta didik. Peserta didik harus terus dilatih untuk memiliki kemampuan berpikir tingkat tinggi, agar peserta didik dalam memahami materi yang dipelajari dengan baik [7].

Terdapat empat persyaratan instrumen tes yang baik, yaitu: valid atau tepat digunakan untuk menilai; reliabel atau dapat dipercaya artinya data yang dikumpulkan benar atau tidak palsu; praktibel artinya instrumen tersebut mudah digunakan; ekonomis yaitu tidak boros dalam mewujudkan dan menggunakan sesuatu di dalam pe-nyusunan, tidak membuang waktu dan tenaga [8]. Langkah-langkah menyusun soal tes yang baik yaitu: merujuk pada kompetensi dasar yang terdapat dalam silabus, menyusun kisi-kisi soal, menyusun butir soal, me-laksanakan uji coba tes, membuat pedoman penskoran (rubrik) [9].

Untuk mewujudkan tujuan pelaksanaan pembelajaran fisika yang terintegrasi dalam pendidikan karakter, maka dalam penelitian ini dikembangkan instrumen penilaian sebagai aspek kognitif. Adapun beberapa penelitian yang bekaitan dengan instrumen tes yang bertujuan untuk mengembangkan instrument keterampilan berpikir tingkat tinggi fisika (PhysTHOTS) peserta didik SMA dan mendapatkan karakteristik PhysTHOTS dan instrumen HOTS PhysTHOTS yang dikembangkan memenuhi syarat digunakan untuk mengukur keterampilan berpikir tingkat tinggi fisika peserta didik SMA [10]. Penelitian selanjutnya bertujuan untuk menganalisis keterkaitan antara pola keterampilan berpikir dengan penguasaan konsep peserta didik pada pembelajaran strategi metakognisi berbantuan thinking map [11].

\section{METODE}

Penelitian ini merupakan penelitian pengembangan yang menghasilkan sebuah produk, yaitu instrumen pengukur HOTS peserta didik kelas X. Model penelitian ini diadaptasi dari model pengembangan yang dibuat oleh Mardapi (2008, p.88) yaitu: (1) menyusun spesifikasi tes, (2) menulis soal tes, (3) menelaah soal tes, (4) melakukan uji coba tes, (5) menganalisis butir soal, (6) memperbaiki tes, dan (7) merakit tes. Adapun teknik pengumpulan data yang digunakan dalam penelitian ini adalah tes tertulis, sedangkan instrumen pengumpulan datanya berupa soal uraian, pilihan ganda, dan jawaban singkat. Uji coba instrumen ini dilakukan di kelas X SMA Negeri 1 Tinambung, Polewali Mandar.

Data yang diperoleh dari respon jawaban peserta didik dianalisis dengan menggunakan bantuan Microsoft Excel untuk analisis soal pilihan ganda. Analisis butir soal digunakan untuk mengetahui karakteristik butir soal yang meliputitingkat kesukaran, daya pembeda, dan penyebaran pilihan jawaban/options (pengecoh) untuk soal pilihan ganda, sedangkan statistic soal akan diperoleh karakteristik perangkat soal yaitu 
rata-rata, standar deviasi, tingkat kesukaran, daya pembeda, koefisien reliabilitas, dan SEM.

\section{HASIL DAN DISKUSI}

\section{Hasil Pengembangan}

Hasil pengembangan dalam penelitian ini adalah instrumen asesmen yang berupa soal tes pilihan ganda dan uraian mata pelajaran fisika SMA kelas X yang valid dan reliabel. Instrumen asesmen yang dikembangkan telah melewati tahap penilaian yang dilakukan dengan uji coba di lapangan. yang melibatkan 20 peserta didik.

\section{Hasil Uji Coba Produk Validitas}

Validasi ini bertujuan untuk mengetahui tingkat validasi tiap butir instrument yang telah dikembangankan.

Tabel 1. Hasil validasi Butir Soal

\begin{tabular}{cll}
\hline No & Validitas Instrume & Nomor Soal \\
\hline 1 & Valid Sangat Tinggi & - \\
2 & Valid Tinggi & $3,6,7,16$ \\
3 & Valid Sedang & 4 \\
4 & Valid Rendah & 2 \\
5 & Valid Sangat Rendah & $5,10,14,17$ \\
6 & Tidak Valid & $9,12,15$ \\
7 & Tidak Terdefenisi & $1,8,11,13,18,19,20$ \\
\hline
\end{tabular}

Hasil validasi terhadap 20 butir soal seperti terlihat pada tabel 1, diperoleh hasil bahwa, 4 soal diperoleh valid tinggi, 1 soal dengan validitas sedamg, 1 soal dengan validitas rendah, validitas sangat rendah 4 soal, 3 soal sangat valid, dan 7 soal tdak terdefenisi.

\section{Reabilitas}

Hasil estimasi reliabilitas instrumen yang dikembangkan menunjukkan hasil yang kurang memuaskan. Berdasarkan hasil estimasi reliabilitas instrumen pada Tabel 9 diperoleh informasi bahwa nilai koefisien Cronbach's Alpha pada soal tidak reliabel.

Tabel 2. Reabilitas Instrumen

\begin{tabular}{cll}
\hline No & Paket Soal & $\begin{array}{l}\text { Nilai Reabilitas } \\
(\mathbf{r 1 1})\end{array}$ \\
\hline 1 & Instrumen Tes & $-0,023072486$ \\
\hline & Nilai reabilitas yang diperoleh adalah - \\
0,023072486 menunjukkan bahwa instrumen tes \\
yang disusun memperoleh r11 < 0,20 artinya \\
realibilitas sangat rendah. Dari hasil yang
\end{tabular}

diperoleh, ini menunjukkan bahwa instrumen yang yang disusun tidak dapat digunakan secara berulang pada peserta didik. Koefisien reliabilitas dapat dilihat pada tabel 3 sebagai berikut:

Tabel 3. Kriteria Koefisien Reliabilitas

\begin{tabular}{cc}
\hline Nilai & Keterangan \\
\hline $\mathrm{r} 11<0,20$ & Sangat Rendah \\
$0,20 \leq \mathrm{r} 11<0,40$ & Rendah \\
$0,40 \leq \mathrm{r} 11<0,70$ & Sedang \\
$0,70 \leq \mathrm{r} 11<0,90$ & Tinggi \\
$0,90 \leq \mathrm{r} 11<1,00$ & Sangat Tinggi \\
\hline
\end{tabular}

\section{Tingkat Kesukaran}

Langkah kegiatan analisis selanjutnya adalah menentukan tingkat kesukaran untuk masing-masing butir soal pada setiap paket soal. Tingkat kesukaran butir dapat dilihat Tabel 4.

Tabel 4. Tingkat Kesukaran Instrumen Tes

\begin{tabular}{clc}
\hline No & Tingkat Kesukaran & Persentase \\
\hline 1 & Soal Sangat Sukar & $25 \%$ \\
2 & Soal Sukar & $0 \%$ \\
3 & Soal Sedang & $15 \%$ \\
4 & Soal Mudah & $60 \%$ \\
5 & Soal Sangat Mudah & $0 \%$ \\
\hline \multicolumn{2}{c}{ Berdasarkan tabel 4, diperoleh persentase }
\end{tabular}
paling tinggi adalah tingkat kesukaran instrumen tes sangat rendah yaitu $60 \%$. Adapun persentase yang lain adalah $25 \%$ untuk kategori soal sangat sukar diselesaikan. Sedangkan untuk kategori soal sedang memperoleh persentase $15 \%$, dengan demikian dapat dikatakan bahwa instrumen tes yang disusun memenuhi kategori sedang untuk digunakan.

\section{Daya Beda}

Langkah kegiatan analisis selanjutnya adalah menentukan daya pembeda untuk masingmasing butir soal pada setiap paket soal. Hasil analisis data menunjukkan bahwa tidak semua butir soal daya pembedanya baik, se-hingga ada butir-butir soal yang perlu direvisi/ diperbaiki atau diganti/dibuang. Selengkapnya peneliti disajikan pada Tabel 5.

Tabel 5. Daya Beda Instrumen tes

\begin{tabular}{clc}
\hline No & Kategori daya beda & Persentase \\
\hline 1 & Sangat Baik & $5 \%$ \\
2 & Baik & $10 \%$ \\
3 & Cukup & $0 \%$ \\
4 & Tidak Baik & $85 \%$ \\
\hline
\end{tabular}


Berdasarkan tabel 5, diperoleh data untuk kategori daya beda tidak baik memperoleh persentase paling tinggi yaitu $85 \%$. Untuk kategori sangat baik dan baik masing-masing memperoleh persnetase 5\% dan 10\%. Olehnya itu, dapat dikataan bahwa daya pembeda instrumen tes yang disusun memiliki daya pembeda tidak baik.

\section{SIMPULAN}

Setelah melakukan analisis terhadap kualitas instrumen tes bentuk tes objektif mata pelajaran Fisika dengan materi Gerak Lurus Beraturan dan Gerak Lurus Berubah Bearturan di SMA Negeri 1 Tinambung dapat ditarik kesimpulan bahwa hasil tes tentang analisis instrumen adalah memiliki kualitas nilai "Rendah". Hal ini ditunjukkan hasil penelitian yang telah dilakukan, terutama ditinjau oleh segisegi berikut.

Pertama ditinjau dari segi validitas itemnya ( $100 \%$ ) soal sesuai dengan isi kurikulum, dari 20 butir soal tes bentuk pilihan ganda yang diselenggarakan di SMAN 1 Tinambung, soal sebanyak 10 butir soal yang dinyatakan valid, 3 butir soal yang dinyatakan tidak valid dan 7 butir soal yang tidak terdefenisi. Dari hasil analisis dapat disimpulkan bahwa data tersebut mempunyai validitas "rendah". Dan dilihat dari segi realibilitas item, diperoleh koefisien (r11) sebesar -2,34178305 dengan demikian bahwa tes tersebut mempunyai reliabilitas "Tidak Valid".

Kedua dilihat dari segi tingkat kesukaran item, diperoleh informasi bahwa pada tes tersebut terdapat $25 \%$ butir soal dalam kategori soal sangat sukar, $15 \%$ butir soal sedang dan $60 \%$ yang termasuk dalam kategori mudah. Berdasarkan hasil presentase tersebut dapat dinyatakan, bahwa tes tersebut mempunyai tingkat kesukaran yang "Sedang". Dan dilhat dari segi daya pembeda item tes, berdasarkan hasil analisa terhadap daya pembeda item tes dapat diperoleh informasi bahwa dalam tes tersebut terdapat $85 \%$ butir soal memiliki daya pembeda tidak baik, $10 \%$ butir soal memiliki daya pembeda cukup, $5 \%$ memiliki daya pembeda sangat baik. Berdasarkan persentase tersebut dapat disimpulkan bahwa daya pembeda tes tersebut mempunyai daya pembeda yang "Tidak baik".

\section{DAFTAR PUSTAKA}

[1] Budiman. A, Jailani. 2014. Pengembangan Instrumen Asesmen Higher Order Thinking Skill (Hots) Pada Mata Pelajaran Matematika Smp Kelas VIII Semester 1. Jurnal Riset Pendidikan Matematika, 1(2). 139-151.

[2] Depdiknas. (2007). Peraturan Menteri Pendidikan Nasional Republik Indonesia Nomor 16, Tahun 2007, tentang Standar Kualifikasi Akademik dan Kompetensi Guru.

[3] Van de Walle, J. A. (2007). Elementary and middle schoolmathematics: teaching developmentally, (6th ed.). United States of America: Pearson Education, Inc.

[4] Arifin. Z, Retnawati. H,. 2017. Pengembangan Instrumen Pengukur Higher Order Thinking Skills Matematika Siswa SMA Kelas X. PYTHAGORAS: Jurnal Pendidikan Matematika, 12 (1). 98-108. http://journal.uny.ac.id/index.php/pythagoras

[5] Depdiknas. (2007). Peraturan Menteri Pendidikan Nasional Republik Indonesia Nomor 20, Tahun 2007, tentang Standar Penilaian Pendidikan.

[6] Dewi, Nastitisari. 2016. Analisis Kemampuan Berpikir Kompleks Siswa Melalui Pembelajaran Berbasis Masalah Berbantuan Mind Mapping. Jurnal EduSains. Vol 8 No 1.

[7] Pratiwi, Umi. 2015. Pengembangan Instrumen Penilaian HOTS Ber-basis Kurikulum 2013 Terhadap Sikap Disiplin. Jurnal Penelitian dan Pembelajaran IPA. Vol 1 No 1.

[8] Arikunto, Suharsimi. 2013. Dasar dasar Evaluasi Pendidikan. Jakarta: PT Bumi Aksara.

[9] Kadir, Abdul. 2015. Menyusun dan Menganalisis Tes Hasil Belajar. Jurnal Alta'dib. Vol 8 No 2.

[10] Istiyono, E., D., Mardapi, danSuparno.2014. Pengembangan Tes kemampuan Berpikir Tingkat Tinggi Fisika (physTHOTS) Peserta Didik SMA. Jurnal Penelitian dan Evaluasi Pendidikan. 18(1): 1-12.

[11] Puspitasari, D. R., L. Yuliati., dan S. Kusairi. 2014. Keterkaitan Antara Pola Keterampilan Berpikir dengan Penguasaan Konsep Siswa Pada Pembelajaran Strategi Metakognisi berbantuan Peta Konsep. Indonesian Journal of Apllied Physics. 4(2): 142- 148. 